\title{
Physicochemical quality of low fat mayonnaise using whey protein concentrate
}

\author{
Tri Umar Satriawan ${ }^{1}$, Herly Evanuarini ${ }^{2,}$, , and Imam Thohari ${ }^{2}$ \\ ${ }^{1}$ Master Program of Animal Science, Faculty of Animal Science, Universitas Brawijaya, Jl. Veteran, \\ Kota Malang, East Java, 65145, Indonesia \\ ${ }^{2}$ Department of Animal Product and Technology, Faculty of Animal Science, Universitas Brawijaya, \\ Jl. Veteran, Kota Malang, East Java, 65145, Indonesia
}

\begin{abstract}
Low fat mayonnaise as a low-calorie product modification has low emulsion stability. Whey Protein Concentrate (WPC) has a high protein content and can act as a good emulsifier for emulsion of mayonnaise. The purpose of this study was to evaluate of a low-fat mayonnaise using WPC based on $\mathrm{pH}$, moisture content, viscosity, and protein content. The materials used are egg yolk, sunflower seed oil, vinegar, WPC, and other complementary materials. This study used a laboratory experiment with a completely randomized design with 4 treatments and 4 replications. The treatment using control treatment without additional use of WPC and treatments using WPC as much as $5 \%, 10 \%$, and $15 \%$ of the total oil use. The variables measured were $\mathrm{pH}$, moisture content, viscosity, and protein. The results showed that the use of WPC in mayonnaise gave significantly different on $\mathrm{pH}$, moisture content, viscosity, and protein content. The conclusion of this research that the use of WPC as much as $15 \%$ produces the best low fat mayonnaise.
\end{abstract}

\section{Introduction}

Mayonnaise an oil-in-water emulsion product consisting of a dispersed phase and a dispersing phase and is stabilized with egg yolk as an emulsifier. Mayonnaise on the market is classified as a high-fat food because lipid as the main components. Lipid contributes $9 \mathrm{kcal}$ per $\mathrm{g}$.

Currently, consumers are more selective towards foods that contain excess lipid. Restrictions on lipid consumption are influenced by the increasing development of science and human awareness of a healthy lifestyle. So that some processed foods are designed to contain low fat.

Some products that reduce the oil content in food include mayonnaise products, namely low-fat mayonnaise, reduce fat mayonnaise, and light fat mayonnaise. The manufacture of low-fat products is done by lowering the oil phase and increasing the water phase. This will cause instability of the emulsion, so it is necessary to use an emulsifier and stabilizer to improve the quality of mayonnaise.

\footnotetext{
* Corresponding author: herlyfptub@ub.ac.id
} 
The stabilizer serves to reduce the interfacial interaction on the oil surface. The materials that are often used to improve emulsions such as protein ingredients. This material is used because it has the ability as a good emulsifier, so it can reduce the interfacial tension of oil and water. Emulsifiers are used to help bind oil and water because they have two sides, which are hydrophobic and hydrophilic. Herald et al. [1] stated that emulsifiers can use ingredients such as modified corn flour, wheat protein, whey protein, and chewing gum. The utilization of whey protein as a processing ingredient is very helpful in the food industry. According to Sun et al. [2] revealed that the use of whey protein concentrate and pectin can be a fat mimetic, the use of $20 \%$ fat mimetic in low-fat mayonnaise displays good gel formation.

Cheese-making by-products such as whey need to be reused. Environmental pollution can also occur in whey disposal sites due to the uncontrolled decomposition process. The good nutritional content of whey if discarded can grow bacteria easily. So the use of whey needs to be increased for commercial purposes and to protect the environment where cheese products are processed. The use of whey protein in mayonnaise needs to be known as an effort to improve the quality of low-fat mayonnaise.

\section{Material and methods}

\subsection{Research Material}

The research materials used in mayonnaise production are sunflower seed oil and commercial whey protein concentrate which has $80 \%$ protein content in powder form purchased from an e-commerce store. The ingredients such as egg yolks of Isa Brown chicken were obtained from the Dau Malang Regional Livestock. Other ingredients used are vinegar or vinegar brand S\&W, mustard brand Maestro, sugar, salt, and white pepper.

\subsection{Research procedure}

The research method used is a laboratory experiment method using a completely randomized design (CRD) with 4 treatments and 4 replications. Control treatment (P0) was made using sunflower seed oil as much as 70\%. All treatment samples used 30\% sunflower seed oil. Treatment includes the use of whey protein percentage. P1 uses a whey protein percentage of $5 \%$. P2 uses a whey protein percentage of $10 \%$. P3 uses a whey protein percentage of $15 \%$.

\subsection{Variable}

The variables observed were $\mathrm{pH}$, water content, viscosity, protein content.

\subsection{1 $\mathrm{pH}$}

$\mathrm{pH}$ measurements were carried out using a $\mathrm{pH}$ meter. The $\mathrm{pH}$ meter tool was calibrated using a solution $\mathrm{pH} 4$ and $\mathrm{pH}$ 7. The $\mathrm{pH}$ meter is dipped into a $\mathrm{pH} 7$ solution, then $\mathrm{pH} 4$, and dipped into a sample that has been diluted with aquades in a ratio of 1: 10. After each dip, make sure it is dry before moving on to the next step [3]. 


\subsubsection{Moisture content}

Moisture content is determined by applying heat to the sample at $110^{\circ} \mathrm{C}$. Rusalim et al. [4] stated that determining the moisture content of feed using the proximate analysis oven method took 4 hours to produce constant dry matter.

\subsubsection{Viscosity}

Viscosity is measured based on the viscosity of the mayonnaise flow in the tester glass. The next step is to install the spindle on the viscometer and lower it into the mayonnaise to the spindle line. The spindle head is positioned in the center of the sample. Turn on the viscometer and read the viscosity on the tool, the calculation is carried out. It was repeated 3 times for each sample [5].

\subsubsection{Protein content}

Protein content measured in crude protein mayonnaise samples determined by the stages of destruction, distillation and titration [3].

\subsection{Data analysis}

The data obtained were analyzed using Microsoft Excel software and then searched for the average and standard deviation. Data were analyzed using Analysis of Variance (ANOVA) and if the results were significantly different or very significant, then further tested using Duncan's Multiple Distance Test (DMRT).

\section{Results and discussion}

\subsection{The effect of whey protein addition on pH of low-fat mayonnaise}

The results of the analysis of variance showed that the addition of whey protein with different percentages in low-fat mayonnaise had a significant effect on the $\mathrm{pH}$ value. The average value of $\mathrm{pH}$ can be seen in Table 1.

Table 1. Average $\mathrm{pH}$ value

\begin{tabular}{|c|c|}
\hline Treatment & $\mathrm{pH} \pm \mathrm{SD}$ \\
\hline $\mathrm{P}_{0}$ & $4.23 \pm 0.05^{\mathrm{a}}$ \\
\hline $\mathrm{P}_{1}$ & $4.68 \pm 0.10^{\mathrm{b}}$ \\
\hline $\mathrm{P}_{2}$ & $4.73 \pm 0.05^{\mathrm{b}}$ \\
\hline $\mathrm{P}_{3}$ & $4.83 \pm 0.05^{\mathrm{b}}$ \\
\hline
\end{tabular}

The average $\mathrm{pH}$ value ranged from 4.23 to 4.83 . The highest mean value of 4.83 was obtained from the treatment using the addition of whey protein P3 and the lowest average value of 4.23 was obtained from the treatment without the addition of whey protein $\mathrm{P} 0$. The results showed that the higher the percentage of addition of whey protein, the $\mathrm{pH}$ value of low-fat mayonnaise will increase.

The results of the study at P0 were control treatments such as commercial mayonnaise which had an acidic atmosphere with an average $\mathrm{pH}$ value of 4.23. This is in accordance with the opinion of Rizkyyani et al. [6] that the addition of banana peel mayonnaise to the control sample has a $\mathrm{pH}$ of 4.43. According to Badan Standarisasi Nasional [7] stated that the 
mayonnaise control sample had an average of 4.1. The average $\mathrm{pH}$ value of the mayonnaise control is not much different because it uses almost the same ingredient formulation.

The use of whey protein makes the mayonnaise sample higher based on the average $\mathrm{pH}$ value. Whey protein comes from the separation of milk fat, so the $\mathrm{pH}$ value of whey protein is almost the same as the $\mathrm{pH}$ value of milk. The $\mathrm{pH}$ of milk is according to Guo et al. [8] from 6.3 to 6.8. According to Badan Standarisasi Nasional [9], sweet whey is obtained from the cheese-making process using an inoculant with a $\mathrm{pH}$ above 5.6 during ripening (Cheddar and Mozzarella) while sour whey is obtained from a cheese-making process using an inoculant with a $\mathrm{pH}$ below 5.6 (Cottage).

\subsection{The effect of whey protein addition on moisture content of low-fat mayonnaise}

The addition of whey protein with different percentages in low-fat mayonnaise has a significant effect on moisture content. The average value of moisture content can be seen in table 2 .

Table 2. The average value of water content $\%$

\begin{tabular}{|c|c|}
\hline Treatment & Water Content \pm SD \\
\hline $\mathrm{P}_{0}$ & $19.05 \pm 0.48^{\mathrm{a}}$ \\
\hline $\mathrm{P}_{1}$ & $18.53 \pm 0.28^{\mathrm{b}}$ \\
\hline $\mathrm{P}_{2}$ & $17.10 \pm 0.50^{\mathrm{c}}$ \\
\hline $\mathrm{P}_{3}$ & $15.81 \pm 0.40^{\mathrm{c}}$ \\
\hline
\end{tabular}

The moisture content values range from 15.81 to 19.05 . The highest mean value of 19.05 was obtained from the treatment without the addition of whey protein $(\mathrm{P} 0)$ and the lowest average value of moisture content of 15.81 was obtained from the treatment using the addition of $15 \%$ whey protein. The results showed that the higher the percentage of addition of whey protein, the lower the moisture content of low-fat mayonnaise produced.

The standard of moisture content in mayonnaise products is set by Widodo et al. [10], a maximum of $30 \%$. Low-fat mayonnaise product with the addition of whey protein according to standards.

Badan Standarisasi Nasional [7] state that the control sample of mayonnaise products has an average value of 18.17. In the control sample, the low-fat mayonnaise product has an average value of 19.05. This is because low-fat mayonnaise reduces the oil and vinegar phases as the water phase of full-fat mayonnaise, thereby increasing the water phase.

The use of whey protein in low-fat mayonnaise can reduce moisture content. This is because the whey protein used is in the form of a powder (solid), so it can bind water. Whey protein absorbs water more easily because it is made from milk that has been separated from the fat component. This is in accordance with the opinion of Evanuarini et al. [11] which states that the cause of water-insoluble in powdered milk is because there is a non-polar fat content. The lower the mixture of fat components, the more easily the whey dissolves in water.

\subsection{The effect of whey protein addition on viscosity of low-fat mayonnaise}

The results of the analysis of variance showed that the addition of whey protein with different percentages in low-fat mayonnaise had a significant effect on the viscosity value. The average value of viscosity can be seen in Table 3 . 
Table 3. The average value of cPs. viscosity

\begin{tabular}{|c|c|}
\hline Treatment & Viscosity \pm SD \\
\hline $\mathrm{P}_{0}$ & $1070 \pm 29^{\mathrm{a}}$ \\
\hline $\mathrm{P}_{1}$ & $1350 \pm 22^{\mathrm{b}}$ \\
\hline $\mathrm{P}_{2}$ & $1580 \pm 29^{\mathrm{c}}$ \\
\hline $\mathrm{P}_{3}$ & $1700 \pm 26^{\mathrm{d}}$ \\
\hline
\end{tabular}

Table 1 . This shows that the viscosity values range from 1070 to 1700 . The highest mean value of 1700 was obtained from the treatment using the addition of whey protein P3 and the lowest average value of 1070 was obtained from the treatment without the addition of whey protein $\mathrm{P} 0$. The results showed that the higher the percentage of addition of whey protein, the higher the viscosity value of low-fat mayonnaise produced.

Reduction of oil in low-fat mayonnaise which results in a decrease in viscosity modified by the addition of carbohydrates in the form of pectin from watermelon rind flour can produce good viscosity because carbohydrates have the potential to bind water [12]. Azizah et al. [13] added that the addition of surfactants to mayonnaise can increase the viscosity of the product. Whey protein has a protein content of $80 \%$ capable of acting as a surfactant for oil and water.

\subsection{The effect of whey protein addition on low-fat mayonnaise protein levels}

The results of the analysis of variance showed that the addition of whey protein with different concentrations in low-fat mayonnaise had a significant effect on the value of protein content. The average value of water content can be seen in table 4 .

Table 4. The average value of protein content $\%$

\begin{tabular}{|c|c|}
\hline Treatment & Protein content \pm SD \\
\hline $\mathrm{P}_{0}$ & $1.46 \pm 0.05^{\mathrm{a}}$ \\
\hline $\mathrm{P}_{1}$ & $1.78 \pm 0.10^{\mathrm{b}}$ \\
\hline $\mathrm{P}_{2}$ & $2.03 \pm 0.17^{\mathrm{c}}$ \\
\hline $\mathrm{P}_{3}$ & $2.47 \pm 0.08^{\mathrm{d}}$ \\
\hline
\end{tabular}

The value of protein content ranges from 1.46 to 2.47. The highest mean value of 2.47 was obtained from the treatment using the addition of whey protein $\mathrm{P} 3$ and the lowest average value of 1.46 was obtained from the treatment without the addition of whey protein $\mathrm{P} 0$. The results showed that the higher the percentage of addition of whey protein, the higher the protein content of low-fat mayonnaise produced.

The results showed that the addition of whey protein can increase the average protein content of low-fat mayonnaise because the addition of ingredients containing whey protein concentrate is $80 \%$. The whey protein component is dominated by -lactoglobulin, lactalbumin, serum albumin, lactoferrin, immunoglobulin, and several other proteins [9].

The results of the addition of whey protein increased significantly beyond the standard set by the Indonesian National Standardization Agency. The highest value of low-fat mayonnaise is 1.80. while the SNI mayonnaise protein content according to [10]. 


\section{Conclusion}

The conclusion of this study is that the addition of $15 \%$ whey protein will improve the physicochemical quality of low-fat mayonnaise.

\section{Reference}

1. T. J. Herald, M. Abugoush, F. Aramouni, J. Texture Stud. 40, 692-709 (2009)

2. C. Sun, R. Liu, B. Liang, T. Wu, W. Sui, M. Zhang, Food Res Int. 108, 151-160 (2018)

3. B. D. Ahadi, M. Y. Effendi, Jurnal Ilmu Peternakan Terapan 2, 34-38 (2019)

4. M. M. Rusalim, T. Gusnawaty, Jurnal Sains dan Teknologi Pangan 2, 770-778 (2017)

5. H. Evanuarini, A. Susilo, IOP Conf. Ser. Earth Environ. Sci. 478, 1-5 (2020)

6. P. Rizkyyani, A. Khusna, M. Hilmi, M. H. Khirzin, D. Triasih, Jurnal Ilmu dan Teknologi Peternakan Tropis 7, 52-58 (2018)

7. Badan Standarisasi Nasional, SNI 3141.1:2011, Susu Segar-Bagian 1: Sapi (Badan Standarisasi Nasional, Jakarta, Indonesia, 2011)

8. M. Guo, G. Wang, in Whey Protein Production, Chemistry, Functionality, and Applications, edited by M. Guo (John Wiley \& Sons Ltd, New Jersey, USA, 2019), pp. $1-12$

9. Badan Standar Nasional, Standar Mutu Mayonnaise (Badan Standarisasi Nasional, Jakarta, Indonesia, 1998)

10. Widodo, A. V. Rahmawati, R. Chulaila, I. G. S. Budisatria, Jurnal Teknologi dan Industri Pangan 13, 132-139 (2012)

11. H. Evanuarini, D. Amertaningtyas, D. T. Utama, IOP Conf. Ser. Earth Environ. Sci 788, $1-7(2021)$

12. K. Wynne, J. Phys. Chem. Lett. 8, 6189-6192 (2017)

13. N. Azizah, K. Suradi, J. Gumilar, Jurnal Ilmu Ternak Universitas Padjadjaran 18, 79-85 (2018) 